\title{
Applying Active Learning Methods to the Design of Library Instruction for a Freshman Seminar
}

\section{Katherine Strober Dabbour}

Active learning methods were employed in designing library instruction for an experimental freshman seminar at California State UniversitySan Bernardino. Rather than rely on the traditional lecture/demonstration format, the centerpiece of the ninety-minute "one-shot" sessions was a small-group, self-guided exercise focusing on the library's online system. As a prelude to the hands-on exercise, students participated in class discussions on the importance of information literacy. Opportunities for individual instruction also were provided. Student, librarian, and faculty evaluations of the sessions were favorable.

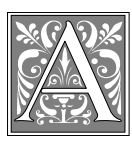

ccording to numerous studies, for-credit freshman seminars are a positive influence on student retention; academic performance, knowledge, and utilization of student services and activities; and personality development, as well as on freshman subpopulations. ${ }^{1}$ Today, approximately 67 percent of American colleges and universities offer some type of freshman seminar, providing librarians with increased opportunities to enhance the library skills of first-year students. ${ }^{2,3}$

\section{The Freshman Seminar Concept}

Emerging out of the higher education counseling movement at the beginning of the twentieth century, freshman orientation was designed to help students make the transition from high school to college. ${ }^{4}$ The terms freshman orientation and freshman seminar have some distinc- tions regarding intellectual content. Freshman orientation "courses," in contrast to one-day or weeklong freshman orientation activities, generally offer extended instruction on college "survival skills" such as note-taking, testing, and time and money management. They also provide a forum for group discussions on social issues. In contrast, freshman seminars are often subject specific, with the goal of introducing students to a particular academic program. However, both terms are generally subsumed under the umbrella phrase freshman seminar. ${ }^{5}$

Freshman seminars are generally forcredit, one- to three-semester-hour (or equivalent quarter-hour) courses, taught by a team of faculty, student affairs personnel, academic administrators, and often librarians. Some colleges and universities require the course of all fresh- 
man students, whereas others keep it elective; they can be either pass/fail or letter graded. ${ }^{6}$

\section{The Freshman Student and Library Instruction}

Bibliographic instruction programs for first-year students traditionally focus on the freshman composition, or English 101 , course, wherein students research and write term papers. Librarians offer courseintegrated instruction on model search strategies, relevant reference materials, and use of the library's catalog and periodical indexes. It is called "course-integrated" instruction because it relates to a specific course assignment. The library literature abounds with examples of freshman course-integrated library instruction, which generally is in the form of lecture/ discussion, demonstration with hands-on practice, workbooks, treasure hunts, and term paper clinics. ${ }^{7}$

However, although conventional wisdom and research support the concept of course-integrated or "just in time" instruction for specific library assignments, what about library instruction for classes that do not include a term paper or any other opportunities for course-integrated library instruction? Will students still benefit from the "just in case," or noncourse-integrated approach to library instruction that goes beyond the traditional overview of library organization and services offered during freshman orientation? At least two previous studies support this approach. ${ }^{8}$ In the case of the freshman seminar, this study asserts that it is not only possible, but necessary.

\section{The Case for Active Learning}

According to numerous research reports and professional educators' associations, active learning methods of instruction are preferable to the more traditional, passive lecture approach. ${ }^{9}$ Although one could argue that, by its very nature, learning is an active process, there is a growing distinction being made in the higher education literature between active and passive learning.

Passive learning generally is defined as the traditional approach to instruction; the teacher presents information during a lecture, and students listen and take notes. In contrast, active learning involves the student in talking and listening, reading, writing, and reflecting; activities that can be performed alone or in combination. According to Meyers and Jones, these activities allow students to clarify, question, consolidate, and appropriate new knowledge. ${ }^{10}$ Although the lecture can meet the needs of highly self-directed individuals, active learning methods provide more opportunities to meet the needs of a variety of learning styles. ${ }^{11}$ Strategies that promote active learning have the following characteristics:

1. Students are involved in more than listening.

2. Less emphasis is placed on transmitting information and more on developing students' skills.

3. Students are involved in higher-order thinking (i.e., analysis, synthesis, and evaluation).

4. Students are engaged in activities (e.g., reading, discussing, writing).

5. Greater emphasis is placed on students' exploration of their attitudes and values. ${ }^{12}$

In concrete terms, teachers can employ activities such as informal, in-class, small-group work; cooperative student projects; simulations, such as role-playing and computer modeling; and case studies to promote active learning. ${ }^{13}$ Allen summarized six specific activities that encourage student participation in the learning process, including the modified lecture, brainstorming, small-group work, cooperative projects, peer teaching and partnering, and writing. ${ }^{14}$

As is the case in the college classroom, traditional bibliographic or library instruction often has been a passive experience for students, with emphasis placed on the librarian's lecture and students 
expected to listen and learn. According to a survey conducted by Barclay and Barclay, 68 percent of college students receive library instruction via the lecture/ demonstration approach. ${ }^{15}$ At the conclusion of the lecture, students are expected to translate the lecture or demonstration into the active process of locating information in the library, most likely several hours or even days later. However, there is increasing evidence in the library literature that an active learning environment is preferable. According to Drueke, hands-on materials such as "worksheets, instructional packets, and self-guided tours have become popular and effective methods" for promoting active library instruction. ${ }^{16}$ She goes on to outline the positive experience of redesigning a traditional bibliographic lecture to include a small-group, hands-on component that encourages student participation in class discussions.

Other uses of the active learning approach to library instruction are found in the literature. A case study approach was used to teach freshman writing composition students the steps to a model search strategy. ${ }^{17}$ Jacobson and Mark relate several small-group exercises that can be used in the process of teaching electronic resources, such as the scope and coverage of periodical indexes, Boolean logic, and search vocabulary choice. ${ }^{18}$ Ragains described the use of Aronson's "jigsaw" method: Small groups of students are asked to examine various titles and figure out what type of information they present, how they would be used, and any limitations. Then, each small group would report its findings to the entire class. ${ }^{19}$

One way to encourage active learning is to incorporate cooperative or collaborative instructional techniques into the lesson. Cooperative learning is the instructional use of small groups of students working on an assignment until each group member successfully understands and completes it. Many researchers have found that cooperative learning techniques are "extremely effective" and preferable to competitive or individualistic methods. ${ }^{20}$ In addition to pedagogical reasons, collaborative learning methods can satisfy the increasing demands of larger classes and rapidly decreasing library resources. For example, Hanson

\section{Active learning involves the student in talking and listening, reading, writing, and reflecting; activities that can be performed alone or in combination.}

cites the inevitability of students having to "share computer terminals, print indexes, and the librarians' time and effort" as a motive for adopting collaborative learning methods in library instruction. ${ }^{21}$ As the following study illustrates, active, collaborative learning methods are preferable to the traditional passive approach, particularly when focused on the library instruction needs of freshman seminar students.

\section{Background and Development of University Studies $\mathbf{1 0 0}$}

California State University-San Bernardino (CSUSB) is a comprehensive public university, part of the 22-campus California State University system. Located near the foot of the San Bernardino Mountains, CSUSB is approximately sixty miles east of downtown Los Angeles, in the area known as the Inland Empire. CSUSB grants bachelor's and master's degrees, teaching credentials, and competency certificates. As of the fall of 1992, its total student population was approximately 12,000 . The average student at CSUSB was in his or her mid-twenties, a first-generation college student, employed full- or part-time, and living offcampus.

The impetus for developing a freshman seminar at CSUSB was its historically low retention rate for undergradu- 
ate students. More than 60 percent of the undergraduates left the university without graduating, which ranked CSUSB nineteenth out of the then twenty California State University campuses. After a couple of experimental classes with limited success rates, a formal two-year pilot program was funded.

The objectives of University Studies (USTD) 100, as outlined in the CSUSB 1992-93 college catalog, were in keeping with a for-credit freshman orientation "course":

An introduction to the academic and practical skills necessary to succeed at the university. Use of library (emphasis added), computer facilities, academic procedures, time management and study skills, responsible academic and personal attitudes. Introduces student to the university in a positive and supportive manner that increases opportunities for success and enhances their academic experience. ${ }^{22}$

Also, the pilot program objectives were to enhance the retention and continuation rates of freshman students who enrolled at the university. In that first quarter, 216 freshman students completed ten sections of USTD 100. Representing 28 percent of the 1992 freshman class of 767 students, they were recruited from the Educational Opportunity Program, honors, and traditional admissions.

\section{Library Involvement in USTD 100}

The CSUSB library had a general collection of more than 560,000 books and bound periodicals, and subscribed to approximately 2,800 serials. Mounted on a KeyNotis integrated online system, the library's OPAC and five Wilson periodical indexes were available on approximately eighteen public terminals in the library, as well as through dial-up access. In addition, various CD-ROM databases and online systems were available from dedicated workstations. Six full-time ref- erence librarians provided "one-shot" library instruction along with reference desk service.

The goals of library instruction for USTD 100 were in keeping with overall course objectives: Students will accept, prefer, and be committed to the value of using library resources for academic inquiry, and will know how to and will use

\section{The impetus for developing a freshman seminar at CSUSB was its historically low retention rate for undergraduate students.}

those resources. Specifically, students would accept, prefer, and be committed to the value of becoming information literate and understand how basic library research skills related to achieving this goal. Furthermore, students would accept, prefer, and be committed to the value of learning how use the library's OPAC, and the Readers' Guide to Periodical Literature and the Social Sciences Index online. Finally, students would be less anxious about their abilities to use the library effectively, knowing that a variety of library resources and staff, particularly reference librarians, were available to help.

\section{Designing Library Instruction with Active Learning Methods}

Given the shortage of reference staffing, the lack of an electronic classroom, and the absence of a specific library assignment, the goals of library instruction for USTD 100 would have to be modest. Although not in keeping with the library's policy of giving priority to course-integrated instruction, the overall goals of the USTD 100 class deserved special attention. Moreover, it was an opportunity to study a fairly homogenous group of students and their reactions to particular methods of library instruction. Therefore, the reference department decided to offer instruction based on active/collaborative learning techniques. 
The focus of the USTD 100 library instruction session was a self-guided, hands-on worksheet exercise. Working in small groups, students performed searches on the library's online system to locate citations to books and articles on predefined topics. Prior to the in-library session, students were required to read their textbook's chapter on library skills. ${ }^{23}$ Librarians hoped that this assignment would inspire students to participate in discussions on the value of information literacy. Students also were asked to individually take the CSUSB Library Walking Tour (a self-guided, four-page handout) so that more time would be available for the hands-on exercise. Having students read materials and perform an activity individually, although not a cooperative learning experience, was in keeping with the characteristics of active learning.

\section{Methodology}

There were ten sections of USTD 100, with an average of twenty-two students enrolled in each. The librarians were allotted one ninety-minute session per section. One librarian conducted each "oneshot" session in the library's classroom and at the online terminals in the reference room, along with the assistance of the instructor and other reference librarians, according to availability. Sessions were staggered over a week to accommodate the librarians' instruction schedules and to prevent one class from dominating the library's scarce computer resources. Signs were placed on most of the public terminals in the reference room to reserve them for one-hour time blocks on each day that instruction was held.

At the start of the twenty-minute discussion in the library's classroom, students were asked to disclose the stereotypes they held of librarians and libraries as an icebreaker. Humorous examples as well as the disclosure of anxieties were encouraged. A discussion of the importance of information literacy or manage- ment, as defined in the Curran chapter of the USTD 100 textbook, followed. ${ }^{24}$ In keeping with one of the characteristics of active learning, the goal of this activity was to engage students in a discussion that emphasized exploration of their attitudes. ${ }^{25}$

\section{Students would possess basic information-management skills to use in their other classes and, hopefully, throughout their lives.}

Next, the goals and objectives of the worksheet exercise were outlined. Librarians encouraged students to complete the worksheet by tying it to the discussion of information literacy. Indeed, by learning how to use the OPAC and some key periodical indexes, students would possess basic information-management skills to use in their other classes and, hopefully, throughout their lives.

Each group of three or four students received one worksheet and had one terminal reserved for them in the reference room. Librarians asked each group to assign one member to fill in answers on the worksheet, another to do the typing, and a third member to read the questions out loud. Although not an optimal situation, groups having four members usually ended up with an additional student "observer." Group members were instructed to switch duties every ten to fifteen minutes to allow each student time for hands-on practice. Librarians and the instructor circulated among the students to answer questions, keep things moving, and remind students to switch duties.

The self-guided, hands-on worksheet exercise was designed to promote student involvement. Students had to read the worksheet instructions and online help screens to answer questions. The cooperative, small-group environment required members to explain their answers to one another. Open-ended ques- 


\begin{tabular}{|c|c|c|c|c|c|c|c|c|}
\hline \multicolumn{9}{|c|}{$\begin{array}{cc}\text { TABLE } 1 \\
\text { Summary Evaluation of Library Instruction } \\
\text { Methods for USTD } 100\end{array}$} \\
\hline \multirow[b]{2}{*}{ Method } & \multicolumn{2}{|c|}{$\begin{array}{c}\text { Very } \\
\text { Valuable }\end{array}$} & \multirow{2}{*}{\multicolumn{2}{|c|}{$\begin{array}{l}\text { Valuable } \\
\mathrm{N}(\%)\end{array}$}} & \multicolumn{2}{|c|}{$\begin{array}{l}\text { Somewhat } \\
\text { Valuable }\end{array}$} & \multicolumn{2}{|c|}{$\begin{array}{c}\text { Not } \\
\text { Valuable }\end{array}$} \\
\hline & $\mathrm{N}$ & $(\%)$ & & & $\mathrm{N}$ & $(\%)$ & $\mathrm{N}$ & $(\%)$ \\
\hline Read chapter & 26 & $14 \%$ & 63 & $34 \%$ & 81 & $44 \%$ & 13 & $7 \%$ \\
\hline Walking tour & 54 & 30 & 83 & 46 & 34 & 19 & 11 & 6 \\
\hline Computer use & 154 & 84 & 26 & 14 & 3 & 1.6 & 1 & 0.5 \\
\hline Worksheet & 68 & 37 & 90 & 49 & 26 & 14 & 0 & 0 \\
\hline Small group & 82 & 44 & 75 & 41 & 24 & 13 & 4 & 2 \\
\hline Discussion & 36 & 19 & 83 & 45 & 58 & 31 & 8 & 4 \\
\hline
\end{tabular}

tions asked students to analyze or evaluate a certain search strategy; for example, students were asked how knowing the subject headings for a certain title would help them locate additional materials.

At the end of the 45-minute worksheet exercise, a twenty-minute follow-up lecture was held in the library's classroom. Librarians attempted to explain the differences between scholarly and popular periodicals, presented examples of other subject indexes, and demonstrated Boolean logic. In addition, librarians stressed the importance of knowing that a type of information resource exists rather than an exact title. This session was designed to reinforce the skills acquired during the hands-on exercise and encourage followup questions. A couple of minutes before the end of class, students filled out evaluation forms.

\section{Evaluation of USTD 100}

Of the 216 students who completed USTD 100, 190 participated in a library instruction session. Of those 190 participants, 185 completed evaluation forms, for a return rate of 97 percent. Fifty-five percent of the students reported previous experience with library instruction in junior high or high school, and 43 percent reported having had no instruction and/or having been self-taught.
Besides answering open-ended questions, students evaluated six instructional activities: reading the library chapter in their textbook, taking a self-guided walking tour of the library, using the OPAC, completing the worksheet exercise, working in small groups, and participating in a class discussion. Respondents rated these components of the session on a four-point scale, from very valuable to not valuable (see table 1).

Fifty-one percent reported that reading a chapter on library research in their textbook was somewhat or not valuable, whereas 48 percent considered it valuable or very valuable. Some of the USTD 100 instructors did not make it an explicit requirement, which might explain the even split. Another factor could be that students, knowing in advance that the textbook exercises were not required, did not bother to read the chapter.

A self-guided walking tour of the library, which used a four-page written guide, was deemed very valuable or valuable by an astounding 76 percent of the students; 25 percent reported it as somewhat or not valuable. ${ }^{26}$ This is suspicious given that none of the librarians could recall seeing anyone, much less 185 freshman students, wandering around the reference room intently studying a library handout. More than likely, students confused taking the elevator from 
the fourth-floor library classroom to the first-floor reference room as a "tour," thereby rendering the question of limited importance. Moreover, the teaching faculty did not uniformly require this component. However, this information could be used to justify revising the session to include a guided tour of the library.

Perhaps the least surprising, but certainly most gratifying, findings were that 98 percent of the students rated learning how to use the library's computer system as very valuable or valuable. Furthermore, 86 percent found the companion worksheet equally valuable. Moreover, 85 percent had the same answer when asked to rate the value of working in small groups. This is consistent with the literature on active and/or collaborative learning. ${ }^{27}$

Students were somewhat less eager, but still positive, about the classroom discussion. Sixty-four percent found it valuable or very valuable, whereas 36 percent found it somewhat or not valuable. Considering responses to the evaluation forms and informal discussions, the librarians were less enthusiastic about using a discussion method of instruction. Most had never conducted a brainstorming-style session using flip charts and actively eliciting class participation. Indeed, they felt uneasy at the perceived lack of student interest or willingness to participate, or both. Perhaps this discrepancy could be attributed to the librarians' ability to hide their discomfort, or that although most students appeared not to participate in the discussion, they appreciated the efforts of their peers.

Students listed the most important thing they learned about using the library in an open-ended question format. Fortyone percent focused on learning to use the computers only. Twenty-one percent mentioned learning about information sources (books, periodicals, libraries, librarians, or a combination) without specifically mentioning computers, whereas
28 percent focused on a combination of using the computers and finding sources of information. Ten percent did not answer the question. An analysis of these open-ended comments could point out that the goals of the session were not stated clearly at the beginning or the methods used did not help students to reach them, or both.

However, when asked to remark on the overall effectiveness of the session, a full 91 percent had only positive comments. This is consistent with an independent, comprehensive evaluation of the USTD 100 course by the CSUSB Undergraduate Studies program. Data from student open-ended evaluations were positive: 84.9 percent of students felt they benefited by participating in the USTD 100 course. Those students who did not felt that the session was a repeat of high school or that they expected more "hands-on" experiences. Eighty-nine percent of the students stated that they would make changes in the USTD 100 curriculum, among them: "Use the library and computers more." ${ }^{28}$ In a campus report on the USTD 100 course by the Undergraduate Studies office, three out of the five instructors specifically mentioned the library in the context of evaluating the content of the course. Library research skills were deemed "most important" along with study and time management skills. Furthermore, the administrator for the course noted that the library was "especially helpful in preparing materials and making presentations." 29

According to a one-year follow-up study by the Undergraduate Studies office, the 1992 freshman class had the highest return rate in the following fall of any freshman class in the nineteen years the university had been tracking these data. The overall 74.7 percent return rate was 8.9 percent higher than the previous year. Of the 28 percent of the freshman students who completed USTD 100 , the return rate was almost 81.5 per- 
cent, which was considered instrumental in bringing the overall freshman return rate to its highest level ever. ${ }^{30}$

\section{Discussion}

Overall, active learning methods of library instruction achieved a positive response from students. However, there is some variation with the types of experiences. Of the five active learning experiences, reading a chapter in the textbook and class discussions garnered the least enthusiasm, whereas working in small groups on a worksheet exercise using computers was of greater interest. A selfguided walking tour is of questionable value for the reasons indicated above.

Recommendations for improvements to the library instruction session came from students, instructional faculty, and

\section{Many students expressed interest in more hands-on practice, including individual workstations, which was not an option at that time.}

librarian participants, both formally and informally. Many students expressed interest in more hands-on practice, including individual workstations, which was not an option at that time. Ideally, a classroom equipped with computers and paired work groups could have facilitated the experience, as well as mitigated reserving public terminals in the reference room. This highlights Hanson's assertion that collaborative learning is inevitable given that most libraries do not have the resources to offer formal, individualized instruction. ${ }^{31}$

A few students recommended that the hands-on exercise also require them to locate actual library materials. Furthermore, informal discussions with instructors and librarians alike revealed that most would have preferred to assign an actual research project to enhance the hands-on activities. Although in keeping with the conventional wisdom of course- integrated library instruction, this study certainly proved that non-course-integrated library instruction has some perceived benefit in a freshman seminar. Additional recommendations for future USTD 100 classes included giving students an actual tour of the library, and providing a summary lecture of library research strategies to reinforce the handson exercise.

In terms of the research methodology used for this study, the author encountered several problems that might have been avoided had circumstances allowed. First of all, there was no opportunity to test the evaluation form before it was distributed. Thus, a few questions had to be discarded because the results indicated that the students misunderstood their intent. Furthermore, the issue of previous experience with library instruction was not adequately explored as a variable influencing the outcome of the study. Indeed, a pre-/post-test might have provided valuable information on the instructional effectiveness of the selfguided exercise. Rather, the evaluation form relied on students' opinions on the quality of the various active learning techniques employed. The questions of Did they learn anything? or Were the instructor's efforts worthwhile? are still unanswered. However, future studies on the effectiveness of employing active learning methods in the delivery of library instruction might benefit from the pre-/post-test method of evaluation.

\section{Conclusion}

Since this study was conducted, the author revised the worksheet exercise several times based on librarian suggestions and an evaluation of students' answers. It also was adapted for other classes, including those with a specific library assignment. A small-group, self-guided worksheet exercise focusing on the General Science Index through the CSUSB library's online system was created for a required sophomore-level biology course 
with approximately 100 students. This exercise was in lieu of a lecture. Although not formally evaluated, students and the course instructor expressed enthusiasm for the approach. Furthermore, a senior-level psychology class also received its primary instruction on using PsycLIT on CD-ROM through the same type of self-guided exercise. The latter class was further challenged by the availability of only one workstation for PsycLIT access. In that situation, students had to work individually, outside class time, thereby lacking the benefit of working in small groups under librarian supervision. Currently, first-year medical students at UCLA receive their primary instruction on the use of MEDLINE by way of a self-guided worksheet exercise, after it was found that the lecture/ demonstration approach did not appeal to these students.

This study demonstrated that the application of active learning techniques for freshman library instruction need not wait for ideal situations - either course-integrated opportunities or a computer training facility. Further, this study confirmed that a small-group, self-guided exercise, under direct librarian supervision, is an attractive method of teaching basic library skills. Indeed, it can be a welcome enhancement to the traditional lecture format as well as the centerpiece of an effective library instruction program.

\section{Notes}

1. Paul P. Fidler and Mary Stuart Hunter, "How Seminars Enhance Student Success," in The Freshman Year Experience: Helping Students Survive and Succeed in College, eds. M. Lee Upcraft, John N. Gardner, and Associates (San Francisco: Jossey-Bass, 1989), 217.

2. Betsy Barefoot, "The Freshman Seminar: A Common Campus Response," Keystone: Newsletter of the Wadsworth College Success Series 1, no. 1 (fall 1992): 1.

3. John N. Gardner, Debra Decker, and Francine G. NcNairy, "Taking the Library to Freshman Students via the Freshman Seminar Concept," in Advances in Library Administration and Organization, eds. Gerard B. McCabe and Bernard Kreissman (Greenwich, Conn.: JAI Pr., 1986), 153-54.

4. Virginia P. Gordon, "Origins and Purposes of the Freshman Seminar," in The Freshman Year Experience, 189.

5. Ibid., 193.

6. Gardner, Decker, and NcNairy, "Taking the Library," 160-61.

7. Gemma S. DeVinney, "Systematic Literature Searching As a Conceptual Framework for Course-Related Bibliographic Instruction for College Freshmen," in Conceptual Frameworks for Bibliographic Education: Theory into Practice, eds. Pamela Kobelski and Mary Reichel (Littleton, Colo.: Libraries Unlimited, 1987), 13-23; Gordon B. Leighton and Marsha C. Markman, "Attitudes of College Freshmen toward Bibliographic Instruction," College \& Research Libraries News 52 (Jan. 1991): 36-38; Sheridan Stormes, “Butler Freshmen Hunt for Library Treasure," College E Research Libraries News 54 (Jul./Aug. 1993): 382-83; Karen A. Becker, "Individual Library Research Clinics for College Freshmen," Research Strategies 11 (fall 1993): 202-10; Joan Parks and Dana Hendrix, "Integrating Library Instruction into the Curriculum through Freshman Symposium," Reference Services Review 24, no. 1 (spring 1996): 65-71.

8. David Lipschutz, "A Practical Approach to Teaching Library Skills to Freshmen," Journal of College Student Personnel 25 (Nov. 1984): 560-61; Paul Coleman, "Give 'Em the Big Picture: Bibliographic Instruction for Freshman Orientation," Research Strategies 4 (summer 1986): 132-35.

9. Charles C. Bonwell and James A. Eison, Active Learning: Creating Excitement in the Classroom, ASHE-ERIC Higher Education Report, no. 1 (Washington, D.C.: George Washington University, 1991), 3-4.

10. Chet Meyers and Thomas B. Jones, Promoting Active Learning: Strategies for the College Classroom (San Francisco: Jossey-Bass, 1993), 21.

11. Eileen E. Allen, "Active Learning and Teaching: Improving Postsecondary Library Instruction," Reference Librarian 51-52 (1995): 92.

12. Bonwell and Eison, Active Learning, 2.

13. Meyers and Jones, Promoting Active Learning, 19.

14. Allen, "Active Learning and Teaching," 96-98.

15. Donald A. Barclay and Darcie Reimann Barclay, "The Role of Freshman Writing in Aca- 
demic Bibliographic Instruction," Journal of Academic Librarianship 20 (Sept. 1994): 216.

16. Jeanetta Drueke, "Active Learning in the University Library Instruction Classroom," Research Strategies 10 (spring 1992): 77-83.

17. Karen Williams and Jennifer Cox, "Active Learning in Action," RQ 31 (spring 1992): 326-31.

18. Trudi E. Jacobson and Beth L. Mark, "Teaching in the Information Age: Active Learning Techniques to Empower Students," Reference Librarian 51-52 (1995): 105-20.

19. Patrick Ragains, "Four Variations on Drueke's Active Learning Paradigm," Research Strategies 13 (winter 1995): 40-50.

20. David W. Johnson, Roger T. Johnson, and Karl A. Smith, "Research on Cooperative Learning," in Cooperative Learning: Increasing College Faculty Instructional Productivity, ASHE-ERIC Higher Education Report, no. 4 (Washington, D.C.: George Washington University, 1991), 27-55.

21. Michele G. Hanson, "Joining the Conversation: Collaborative Learning and Bibliographic Instruction," Reference Librarian 51-52 (1995): 147-59.

22. California State University-San Bernardino, Bulletin, 1992-93 (San Bernardino: California State Univ., 1992).

23. Charles C. Curran, "Becoming an Information-Literate, Self-Reliant Learner," in College Is Only the Beginning: A Student Guide to Higher Education, 2d ed., eds. John N. Gardner and A. Jerome Jewler (Belmont, Calif.: Wadsworth Publishing, 1989): 76-91.

24. Ibid.

25. Bonwell and Eison, "Active Learning," 2.

26. Percentages do not add up to 100 due to rounding off.

27. Johnson, Johnson, and Smith, "Research on Cooperative Learning," 27-55.

28. Office of the Dean of Undergraduate Studies, "First-Year Seminar End of Term Survey: Focus on Student Perceptions" (California State University-San Bernardino, Jan. 1993, photocopy).

29. Office of the Dean of Undergraduate Studies, "Report of the Campus: 1992 and 1993 Pilot Program, First-Year Seminar, University Studies 100, Part 1: Background and Review of the Pilot Program" (California State University-San Bernardino, Nov. 1993, photocopy).

30. Joel Nossoff, "Freshman Seminar Increases University Retention Rate," Friday Bulletin, California State University-San Bernadino (Dec. 17, 1993): 1.

31. Hanson, "Joining the Conversation," 147-48. 